\title{
Short communication: Effect of abomasal inorganic phosphorus infusion on phosphorus absorption in large intestine, milk production, and phosphorus excretion of dairy cattle
}

\author{
X. Feng, ${ }^{* 1}$ P. P. Ray,† J. P. Jarrett, $\ddagger$ L. Karpinski, $\ddagger$ B. Jones, $\ddagger$ and K. F. Knowlton $\ddagger$ \\ ${ }^{*}$ College of Life Science and Engineering, Foshan University, Foshan, China 528000 \\ †Division of Animal, Dairy and Food Chain Sciences, School of Agriculture, Policy and Development, University of Reading, Reading RG6 6AR, \\ United Kingdom \\ †Department of Dairy Science, Virginia Tech, Blacksburg 24061
}

\section{ABSTRACT}

The objective of the study was to evaluate the effect of inorganic phosphorus $(\mathrm{Pi})$ infusion on $\mathrm{P}$ absorption in large intestine, milk production, and phosphorus excretion. Four ruminally and ileally cannulated crossbred cows were used in a $4 \times 4$ Latin square with 21 -d periods. Cows were fed a total mixed ration containing $0.21 \% \mathrm{P}$, providing $50 \%$ of the cows' $\mathrm{P}$ requirement. Cobalt-EDTA was used as marker to measure large intestine digesta flow. On d 13 to 21 of each period, each cow was infused daily with $0,20.1,40.2$, or $60.3 \mathrm{~g}$ of $\mathrm{Pi}$ into the abomasum and total collection was conducted on d 18 to 21 . Ileal samples were collected every $9 \mathrm{~h}$ on d 18 to 21. Feed, digesta, and fecal samples were analyzed for total $\mathrm{P}$ and $\mathrm{Pi}$ using the molybdovanadate yellow method and blue method, respectively. All data were analyzed using PROC GLIMMIX in SAS 9.3 (SAS Institute Inc., Cary, NC) using contrasts to evaluate linear, quadratic, and cubic effects of Pi infusion dose. Dry matter intake, apparent dry matter digestibility, milk yield, and milk total $\mathrm{P}$ were unaffected by $\mathrm{Pi}$ infusion. Ileal flow and fecal excretion of total $\mathrm{P}$ and $\mathrm{Pi}$ increased linearly with increasing infused Pi. In the large intestine, net absorption of $\mathrm{TP}$ and $\mathrm{Pi}$ was increased linearly with increasing infused $\mathrm{Pi}$. The magnitude of absorption from the large intestine was greater than reflected in current models, raising questions that could be evaluated with longer infusion periods or dietary alteration.

Key words: dairy cow, phosphorus absorption, phosphorus excretion

Received January 29, 2018.

Accepted April 10, 2018.

${ }^{1}$ Corresponding author: yangxin@vt.edu

\section{Short Communication}

Manure phosphorus (P) contamination of surface water can impair growth and survival of aquatic species. The strong relationship between dietary $\mathrm{P}$ and manure $\mathrm{P}$ content in most species provides a useful approach to reduce environmental impact of livestock farms, but also makes important detailed knowledge of the fate of the dietary $\mathrm{P}$ and its utilization in the digestive tract. In dairy cattle, absorption of $\mathrm{P}$ mainly occurs in small intestine and is modulated by endocrine factors and nutritional factors (mineral content in the diet, $\mathrm{P}$ content of the diet, and the forms of different $\mathrm{P}$ in diet). Absorption of $\mathrm{P}$ in the large intestine of dairy cattle is rarely reported. Net absorption of $\mathrm{P}$ from large intestine in sheep ranges from 2 to $30 \%$ of the $\mathrm{P}$ flow entering the large intestine (Breves and Schroder, 1991). Sklan and Hurwitz (1985) reported rapid absorption of many ions in the small intestine, but in the large intestine absorption of $\mathrm{P}, \mathrm{Ca}, \mathrm{Mg}$ and $\mathrm{K}$ were low. Smith et al. (1955) reported higher $\mathrm{P}$ concentration in the rectum compared with cecum in sheep, suggesting net secretion of $\mathrm{P}$ in the large intestine. Hoeller et al. (1988) reported net $\mathrm{Pi}$ secretion into the colon with a $\mathrm{Pi}$-free infusate in the colon of sheep and net $\mathrm{Pi}$ uptake with infusate containing 2.5 to $6.5 \mathrm{mmol} / \mathrm{L}$ of $\mathrm{Pi}$. The objective of the current study was to determine the effect of infused $\mathrm{Pi}$ on phosphorus absorption in large intestine, milk production, and phosphorus excretion of dairy cattle

All protocols and procedures were approved by Virginia Tech Institutional Animal Care and Use Committee. Four ruminally and ileally cannulated crossbred [Swedish Red or Brown Swiss $\times($ Holstein $\times$ Jersey)] early-lactation cows averaging 76 DIM $(\mathrm{SD}=38)$ were fed a diet containing $0.21 \% \mathrm{P}$, providing $\sim 50 \%$ of the cows' calculated P requirement (NRC, 2001). Treatments (abomasal infusion of 0, 20.1, 40.2, or 60.3 $\mathrm{g} / \mathrm{d}$ inorganic phosphate solution) were imposed in a $4 \times 4$ Latin square design with 21-d periods. Cows were individually fed in Calan doors (American Calan, 
Northwood, NH) once daily at $1200 \mathrm{~h}$ on d 1 to 7 and 4 times daily at $0600,1200,1800$ and $2400 \mathrm{~h}$ on $\mathrm{d} 8$ and 9 of each period. Cows had constant access to feed except during milking. Feed was offered at 5 to $10 \%$ in excess of the previous day's intake (wet basis). From d 10 to 21 of each period, cows were housed in individual tiestalls with wood shavings as bedding (amount used recorded daily), milked twice daily at 0600 and $1800 \mathrm{~h}$, and fed 4 times daily, as on d 8 and 9 , with continuous access to diet and water. On d 13 to 21 of each period, each cow was infused daily with $0,20.1,40.2$, or $60.3 \mathrm{~g}$ of inorganic phosphate solution into the abomasum. The solution was made of monobasic potassium phosphate with potassium phosphate dibasic anhydrous in double distilled water and the $\mathrm{P}$ concentration of the solution was monitored daily. Cobalt-EDTA (Co-EDTA) was used (dosed $110 \mathrm{mg}$ of $\mathrm{Co} / \mathrm{d}$ ) as a marker to measure digesta flow. Marker was dosed into the rumen through the rumen cannula 4 times per day at each feeding on d 9 to 21 of each period. Feed and feed refusals were sampled daily and stored at $-20^{\circ} \mathrm{C}$. Samples were stored at $-20^{\circ} \mathrm{C}$. On d 19 to 21 , ileal samples and urine samples were collected every $9 \mathrm{~h}$. Total fecal collection was conducted on d 18 to 21 of each period. At 1800 $\mathrm{h}$ on each day, feces were weighed, thoroughly mixed using an electric mixer, and a subsample was taken and stored at $-20^{\circ} \mathrm{C}$. Milk yield was recorded and milk samples collected at 8 consecutive milkings on $d 18$ to 21. Blood samples were obtained on d 20 and 21 of each period via venipuncture in coccygeal veins and saved in Vacuette tubes (Greiner bio-one, Monroe, NC). Serum was separated immediately by centrifugation at 1,850 $\times g$ for 10 min at $4^{\circ} \mathrm{C}$ and then was stored at $-20^{\circ} \mathrm{C}$.

Feed, feed refusals, wood shavings, and total collected fecal samples were thawed at room temperature then dried at $55^{\circ} \mathrm{C}$ forced-air oven (Thermo Scientific Precision 645, Danville, IN) and ground through a 1-mm screen in a Wiley mill (Arthur H. Thomas, Philadelphia, PA). The ileal samples were thawed then pooled on an equal wet basis over the 8 sampling times to yield a composite from each cow on each period. The pooled ileal samples were dried as described above. Ground feed and feed refusals were analyzed in duplicate for DM. Ground feed, feed refusals, wood shavings, total collected fecal samples, and pooled ileal samples were ground further through a $0.2-\mathrm{mm}$ screen (Z-grinder) and analyzed for total $\mathrm{P}$ (yellow molybdovanadate method) and Pi (molybdate blue method; AOAC, 1984). Samples were digested by concentrated nitric acid and perchloric acid for total $\mathrm{P}$ analysis and extracted by $0.5 \%$ hydrochloric acid for Pi analysis. Milk samples were analyzed for fat, protein, SNF, lactose, MUN, and SCC (DHIA, Blacksburg, VA) and P. The composite ileal samples were also analyzed for Co using inductively coupled plasma-MS. Daily urine output was predicted using the equations presented in Holter and Urban (1992) and urinary P excretion was calculated by multiplying daily urine output by TP concentration in urine. The large intestine TP absorption in each treatment was calculated as the difference between ileal TP flow and fecal TP. Excretion of TP was calculated as fecal TP minus TP from wood shavings and urine TP. All data were analyzed using PROC GLIMMIX procedures of SAS (SAS Institute Inc., 2011). In the model, treatment and period were fixed effects and cow was a random effect. Preplanned contrasts were used to evaluate linear, quadratic, and cubic treatment effects of treatment. Differences were declared significant at $P$ $<0.05$ and trends at $P<0.1$.

Despite the very low $\mathrm{P}$ content of the basal diet $(0.21 \%, \sim 50 \%$ of requirement $)$, the infused $\mathrm{Pi}$ dose did not affect digestibility of the DM or fecal DM excretion (Table 1). The $P$-value for cubic contrast on DMI is significant $(P<0.05)$, with cows supplied total $110 \%$ of their $\mathrm{P}$ requirement having DMI higher than in cows supplied 50, 80, or $140 \%$ of requirements. Valk et al. (2002) fed diets containing 67,80 , and $100 \%$ of requirements and observed no effects of dietary $\mathrm{P}$ on DMI or digestibility of DM in dairy cows. In contrast, Call et al. (1987) observed reduced DMI of the cows fed low P $(0.24 \%)$ diet from 2 to $10 \mathrm{wk}$ after parturition, as cows were allotted to the low $\mathrm{P}$ diet 2 mo before expected

Table 1. Effect of abomasal infusion of inorganic phosphorus on DMI and digestibility

\begin{tabular}{|c|c|c|c|c|c|c|c|c|}
\hline \multirow[b]{2}{*}{ Item } & \multicolumn{4}{|c|}{$\mathrm{P}$ supply, ${ }^{1} \%$ of requirement } & \multirow[b]{2}{*}{$\mathrm{SE}$} & \multicolumn{3}{|c|}{$P$-value } \\
\hline & 50 & 80 & 110 & 140 & & Linear & Quadratic & Cubic \\
\hline$\overline{\mathrm{DMI}}, \mathrm{kg} / \mathrm{d}$ & 19.8 & 19.6 & 23.2 & 20.7 & 1.03 & 0.16 & 0.22 & 0.04 \\
\hline $\mathrm{P}$ intake, $\mathrm{g} / \mathrm{d}$ & 42.7 & 41.5 & 45.4 & 43.9 & 2.85 & 0.50 & 0.96 & 0.36 \\
\hline Fecal DM, kg/d & 6.22 & 7.19 & 6.96 & 7.92 & 0.71 & 0.11 & 0.99 & 0.40 \\
\hline DM digestibility, \% & 68.6 & 63.0 & 69.3 & 61.3 & 3.60 & 0.34 & 0.73 & 0.13 \\
\hline
\end{tabular}

${ }^{1}$ Cows were abomasally infused with $0,20.1,40.2$, and $60.3 \mathrm{~g} / \mathrm{d}$ of inorganic P solution to supply $50,80,110$, and $140 \%$ of their calculated $\mathrm{P}$ requirement, respectively. 
Table 2. Effect of abomasal infusion of inorganic phosphorus on milk yield, milk composition and milk total phosphorus concentration

\begin{tabular}{|c|c|c|c|c|c|c|c|c|}
\hline \multirow[b]{2}{*}{ Item } & \multicolumn{4}{|c|}{$\mathrm{P}$ supply, ${ }^{1} \%$ of requirement } & \multirow[b]{2}{*}{$\mathrm{SE}$} & \multicolumn{3}{|c|}{$P$-value } \\
\hline & 50 & 80 & 110 & 140 & & Linear & Quadratic & Cubic \\
\hline Milk yield, $\mathrm{kg} / \mathrm{d}$ & 27.4 & 26.6 & 29.1 & 26.4 & 1.88 & 0.91 & 0.38 & 0.10 \\
\hline Milk P, g/L & 0.93 & 0.87 & 0.89 & 0.91 & 0.03 & 0.53 & 0.10 & 0.41 \\
\hline Fat, $\%$ & 4.98 & 5.05 & 5.27 & 5.39 & 0.18 & 0.12 & 0.90 & 0.77 \\
\hline Protein, \% & 3.29 & 3.27 & 3.36 & 3.22 & 0.15 & 0.67 & 0.40 & 0.24 \\
\hline MUN, mg/dL & 13.8 & 11.9 & 11.1 & 12.0 & 0.92 & 0.18 & 0.20 & 0.88 \\
\hline $\mathrm{SCC}, 1,000 / \mathrm{mL}$ & 29 & 77 & 40 & 75 & 20 & 0.27 & 0.76 & 0.11 \\
\hline
\end{tabular}

${ }^{1}$ Cows were abomasally infused with $0,20.1,40.2$, and $60.3 \mathrm{~g} / \mathrm{d}$ inorganic phosphorus solution to supply 50,80 , 110 , and $140 \%$ of their calculated $\mathrm{P}$ requirement.

parturition. Lack of effect of Pi dose on DM digestion in our study was likely due to the short-term nature of the study.

Milk yield was not affected by treatment (Table 2). The $\mathrm{P}$ content of milk ranged from 0.87 to $0.93 \mathrm{~g} / \mathrm{L}$, similar to values typically observed, with no effect of infused Pi. We found no effect of Pi infusion on milk composition. Call et al. (1987) reported insufficient P in diet decreased milk yield and reduced BW in cows fed diets containing $0.24 \%$ as compared with diets of 0.32 and $0.42 \% \mathrm{P}$ diets in a 12-mo study, and suggested these measures as the initial signs of $\mathrm{P}$ deficiency. In the short term, $\mathrm{P}$ homeostasis is maintained by drawing from the skeletal reserves (Karn, 2001), likely explaining the minimal effects in the current study. Whereas $\mathrm{P}$ intake must be very low for extended periods to impair milk yield, excess $\mathrm{P}$ intake has been reported to reduce milk yield. Carstairs et al. (1981) reported cows fed $35 \%$ more $\mathrm{P}$ than requirement produced $1.8 \mathrm{~kg}$ milk less per day during the experiment. In the present study, few detrimental effects of high and low P intake were observed, but the greater DMI in cows supplied P near to the requirement is of interest (Table 1).

In large intestine, the net absorption of $\mathrm{TP}$ and Pi increased linearly with increasing Pi infused $(P=$ $0.02 ; P=0.004$; Table 3 ), but absorption of these as a percent of ileal flow was not affected $(P=0.32$; data not shown). Fecal TP and Pi increased linearly with increasing infused $\mathrm{Pi}(P<0.01)$. Little quantitative information is available regarding $\mathrm{P}$ absorption from the large intestine of ruminants, especially dairy cattle. In their model, Feng et al. (2015) predicted a small portion of $\mathrm{P}$ was absorbed in the large intestine of dairy cows $(\sim 6 \mathrm{~g} / \mathrm{d})$. In the present study, as the infused $\mathrm{Pi}$ increased, net absorption of TP and Pi in large intestine increased linearly. Net absorption of TP in the large intestine was greater than absorption of $\mathrm{Pi}$, suggesting microbial degradation of phytate or other organic P-containing compounds. In the current study P absorption from the large intestine and retention were higher than has been observed elsewhere, especially in the group of cows infused with Pi $(12.3,15.1$, and 23.7

Table 3. Effect of abomasal infusion of inorganic phosphorus (Pi) on intake and digestibility of total phosphorus (TP) and Pi

\begin{tabular}{|c|c|c|c|c|c|c|c|c|}
\hline Item & \multicolumn{4}{|c|}{$\mathrm{P}$ supply, ${ }^{1} \%$ of requirement } & SE & \multicolumn{3}{|c|}{$P$-value } \\
\hline \multicolumn{9}{|l|}{ Total P } \\
\hline Absorption of $\mathrm{P}$ from $\mathrm{LI}^{2} \mathrm{~g} / \mathrm{d}$ & 6.25 & 12.3 & 15.1 & 23.7 & 3.75 & 0.02 & 0.74 & 0.61 \\
\hline Fecal TP, g/d & 17.0 & 27.1 & 33.2 & 61.4 & 3.26 & $<0.0001$ & 0.002 & 0.02 \\
\hline Milk TP. $\mathrm{g} / \mathrm{d}$ & 25.7 & 22.9 & 25.6 & 23.9 & 1.75 & 0.61 & 0.67 & 0.12 \\
\hline \multicolumn{9}{|l|}{ Inorganic phosphorus (Pi) } \\
\hline Ileal Pi flow, g/d & 8.19 & 16.2 & 27.4 & 52.9 & 3.40 & $<0.0001$ & 0.03 & 0.45 \\
\hline Absorption of Pi from LI, g/d & 0.06 & -1.64 & 6.36 & 15.4 & 2.64 & 0.004 & 0.09 & 0.49 \\
\hline Fecal Pi, g/d & 8.13 & 17.8 & 21.0 & 37.6 & 4.03 & 0.0005 & 0.29 & 0.19 \\
\hline Serum $\mathrm{Pi}, \mathrm{mg} / \mathrm{dL}$ & 3.53 & 5.87 & 6.64 & 6.48 & 0.38 & 0.003 & 0.03 & 0.75 \\
\hline
\end{tabular}

${ }^{1}$ Cows were abomasally infused with $0,20.1,40.2$ and $60.3 \mathrm{~g} / \mathrm{d}$ inorganic $\mathrm{P}$ (Pi) solution to supply 50, 80,110 and $140 \%$ of their calculated $\mathrm{P}$ requirement.

${ }^{2} \mathrm{LI}=$ large intestine.

${ }^{3} \mathrm{P}$ retention $=$ dietary $\mathrm{P}+$ infused $\mathrm{P}-$ fecal $\mathrm{P}-$ urine $\mathrm{P}-$ milk $\mathrm{P}$. 
$\mathrm{g} / \mathrm{d})$. These values may represent the extreme high end of the normal range, but sources of bias must also be considered. The short infusion period and reliance on single markers to estimate ileal flow may be sources of error; the former could be evaluated in future studies.

Blood Pi increased from 3.53 to $6.48 \mathrm{mg} / \mathrm{dL}$ with increasing infused $\mathrm{Pi}(P=0.003)$. Excess absorbed $\mathrm{P}$ beyond animals' requirement is resecreted from the blood into saliva (Ternouth, 1990) and then enters the digestive tract, being reabsorbed or excreted into the feces. Decreased P intake lowered blood Pi concentration and salivary Pi concentration (Valk et al., 2002), suggesting blood $\mathrm{P}$ as an indicator of $\mathrm{P}$ deficiency. Wu et al. (2000) and Knowlton and Herbein (2002) found that with extended $\mathrm{P}$ deficiency resorption of bone $\mathrm{P}$ can occur, making plasma $\mathrm{P}$ a less reliable indicator of body $\mathrm{P}$ status over time. In the current study, infused $\mathrm{Pi}$ linearly increased serum Pi concentration suggesting that blood $\mathrm{P}$ concentration might be used as an indicator of the $\mathrm{P}$ status in a short-term.

We concluded that increasing infused $\mathrm{Pi}$ into abomasum of cows fed diets supplying $\sim 50 \%$ of total $\mathrm{P}$ requirement increased $\mathrm{P}$ flow entering the ileum and increased fecal $\mathrm{P}$ excretion. In the large intestine, net $\mathrm{Pi}$ absorption linearly increased with increasing infused Pi. The magnitude of absorption from the large intestine was greater than reflected in current models, raising questions that could be evaluated with longer infusion periods or dietary alteration.

\section{ACKNOWLEDGMENTS}

This project was supported by National Research Initiative Competitive Grant no. 2009-55206-05267 from the USDA National Institute of Food and Agriculture (Washington, DC).

\section{REFERENCES}

AOAC. 1984. Official Methods of Analysis. 14th ed. Association of Official Analytical Chemists, Arlington, VA.

Breves, G., and B. Schroder. 1991. Comparative aspects of gastrointestinal phosphorus metabolism. Nutr. Res. Rev. 4:125-140.

Call, J. W., J. E. Butcher, J. L. Shupe, R. C. Lamb, R. L. Boman, and A. E. Olson. 1987. Clinical effects of low dietary phosphorus concentrations in feed given to lactating dairy cows. Am. J. Vet. Res. 48:133-136.

Carstairs, J. A., R. R. Neitzel, and R. S. Emery. 1981. Energy and phosphorus status as factors affecting postpartum performance and health of dairy cows. J. Dairy Sci. 64:34-41.

Feng, X., K. F. Knowlton, and M. D. Hanigan. 2015. Parameterization of a ruminant model of phosphorus digestion and metabolism. J. Dairy Sci. 98:7194-7208.

Hoeller, H., A. Figge, J. Richter, and G. Breves. 1988. Calcium and inorganic phosphate net absorption from the sheep colon and rectum perfused in vivo. J. Anim. Physiol. Anim. Nutr. (Berl.) 59:9-15.

Holter, J. B., and W. E. Urban Jr. 1992. Water partitioning and intake prediction in dry and lactating Holstein cows. J. Dairy Sci. $75: 1472-1479$.

Karn, J. F. 2001. Phosphorus nutrition of grazing cattle: A review. Anim. Feed Sci. Technol. 89:133-153.

Knowlton, K. F., and J. H. Herbein. 2002. Phosphorus partitioning during early lactation in dairy cows fed diets varying in phosphorus content. J. Dairy Sci. 85:1227-1236.

NRC. 2001. Nutrient Requirements of Dairy Cattle. 7th rev. ed. Natl. Acad. Press, Washington, DC.

SAS Institute Inc. 2011 SAS/STAT 9.3 User's Guide. SAS Inst. Inc., Cary, NC.

Sklan, D., and S. Hurwitz. 1985. Movement and absorption of major minerals and water in ovine gastrointestinal tract. J. Dairy Sci. 68:1659-1666.

Smith, A. H., M. Kleiber, A. L. Black, and C. F. Baxter. 1955. Transfer of phosphate in the digestive tract. II. sheep. J. Nutr. 57:507-527.

Ternouth, J. H. 1990. Phosphorus and beef production in northern Australia. 3. Phosphorus in cattle-A review. Trop. Grassl. 24:159-169.

Valk, H., L. B. J. Šebek, and A. C. Beynen. 2002. Influence of phosphorus Intake on excretion and blood plasma and saliva concentrations of phosphorus in dairy cows. J. Dairy Sci. 85:2642-2649.

Wu, Z., L. D. Satter, and R. Sojo. 2000. Milk production, reproductive performance, and fecal excretion of phosphorus by dairy cows fed three amounts of phosphorus. J. Dairy Sci. 83:1028-1041. 